\title{
Influence of temperature and light on the growth of young brussels sprout plants ${ }^{1}$
}

\author{
H. G. Kronenberg
}

Department of Horticulture, Agricultural University, Wageningen, the Netherlands

Accepted: 23 December 1974

\section{Summary}

In 1972 and 1973 young brussels sprout plants propagated from cuttings and seed were grown in greenhouses at $9,13,17,21$ and $25^{\circ} \mathrm{C}$ and total radiation between $16500-33000 \mathrm{~J} / \mathrm{cm}^{2}$ at 4 weeks during 4,8 and 12 weeks. Plants from cuttings grew best at $21^{\circ} \mathrm{C}$ and those from seeds at $17^{\circ} \mathrm{C}$. Plant growth was best at 33000 $\mathrm{J} / \mathrm{cm}^{2}$. Radiation between $16500-29000 \mathrm{~J} / \mathrm{cm}^{2}$ did not affect growth.

\section{Introduction}

The methods of growing brussels sprout plants have changed in the last ten years. Formerly sprouts were considered as a late autumn or winter vegetable and supply started in October. Freezing of sprouts, however, has become more important and because they were available the whole year round the demand for fresh sprouts has started earlier (August - September). Sprout plants are now grown earlier in the season. In addition, single harvest of sprouts has become more important mostly for conserving, which was made possible after the development of efficient harvesting machines and better adapted cultivars. Earlier planting was necessary to obtain a high enough yield before winter, however.

Formerly the recommended sowing dates were March to April, but now early in February to April. Corresponding planting dates in the field were the end of May to $15 \mathrm{June}$; they have now been advanced to the end of April up to 15 June (Buishand, 1973). This early sowing is done under Dutch lights instead of in the open.

The cultural changes described above introduced different environmental conditions: earlier in the year temperatures (even under glass) are lower and there is less light (especially under glass). To determine the effect of these changes on the growth of young brussels sprout plants and the possibility of further advancing of planting dates the influences of temperature and light on the growth of young brussels sprout plants were investigated.

1 Publication 409 Laboratorium voor Tuinbouwplantenteelt, Landbouwhogeschool, Wageningen, the Netherlands. 


\section{Materials and methods}

Two experiments were carried out in five air-conditioned greenhouses belonging to the phytotron of the Department of Horticulture at Wageningen (described by Doorenbos, 1964). Temperatures were maintained at $9,13,17,21$ and $25^{\circ} \mathrm{C}$, but were slightly higher at midday on sunny days. Radiation in the greenhouses was measured continuously and averaged $40 \%$ less than measurements in the open.

In both experiments plants were harvested and dried after 4, 8 and 12 weeks of treatment. Dry weights were determined after 2 days at $45^{\circ}$ and 3 days at 75 $80^{\circ} \mathrm{C}$.

Because plants were harvested successively and space in the greenhouse was restricted, only few plants were used per treatment: 2 plants per treatment in 1972 and 3 plants in 1973. In 1972 vegetatively propagated plants from a selected brussels sprout plant of the cultivar 'Sanda' were used as test plants. The mother plant was kept vegetative for years by growing it continuously above $15^{\circ} \mathrm{C}$ for use as a source of cuttings. Cuttings were struck and the young plants potted 3 weeks later in 5-litre $(21 \mathrm{~cm}$ diameter) pots. The experiment was started on 9 May with 5 groups of 8 uniform plants, which were grown for 4,8 and 12 weeks at the abovementioned temperatures. The radiation received after 4,8 and 12 weeks had been 23866,49703 and $77684 \mathrm{~J} / \mathrm{cm}^{2}$, respectively.

In 1973 the normal practice of seeding was used, primarily because the plants from cuttings in 1972 grew rather slowly. Furthermore, plants from cuttings are adult plants and those from seeds are juvenile. The $F_{1}$ hybrid cultivar 'Thor' was selected because it scored highest in the 1972 uniformity tests of the Institute of Horticultural Plant Breeding at Wageningen. Four series, comprising five groups of nine plants each, received different levels of radiation (Table 1). From these, three were harvested and dried after 4, 8 and 12 weeks (Table 2).

\section{Results and discussion}

In 1972 temperature influences after 4 weeks were small (Fig. 1). After 8 and 12 weeks plants grown at $21{ }^{\circ} \mathrm{C}$ were distinctly heavier than at 17 or $25^{\circ} \mathrm{C}$.

In 1973 differences in plant weight of Series 1, 2 and 3 were small, while plants in Series 4 were heavier. Only results of Series 3 and 4 are given (Fig. 2). From

Table 1. Radiation $\left(\mathrm{J} / \mathrm{cm}^{2}\right)$ received by brussels sprout plants after being brought into the greenhouse (1973).

\begin{tabular}{llll}
\hline $\begin{array}{l}\text { Series } \\
\text { number }\end{array}$ & After 4 weeks & 8 weeks & 12 weeks \\
1 & & & \\
2 & 16518 & 38876 & 67845 \\
3 & 22358 & 51327 & 84254 \\
4 & 28969 & 61896 & 92950 \\
\hline
\end{tabular}


Table 2. Growing of young brussels sprout plants early in the year (1973).

\begin{tabular}{|c|c|c|c|c|c|c|}
\hline $\begin{array}{l}\text { Series } \\
\text { number }\end{array}$ & Sowing & $\begin{array}{l}\text { Pricking } \\
\text { off }\end{array}$ & Potting & $\begin{array}{l}\text { Start of } \\
\text { experiments }\end{array}$ & $\begin{array}{l}\text { Duration } \\
\text { of growing } \\
\text { (ditys) }\end{array}$ & $\begin{array}{l}\text { Average dry } \\
\text { weight of } \\
10 \text { plants } \\
\text { (grams) }\end{array}$ \\
\hline $\begin{array}{l}1 \\
2 \\
3 \\
4\end{array}$ & $\begin{aligned} 15 & \text { Jan. } \\
19 & \text { Feb. } \\
28 & \text { Mar. } \\
1 & \text { May }\end{aligned}$ & $\begin{array}{rl}29 & \mathrm{Jan} . \\
5 & \mathrm{Mar} . \\
5 & \mathrm{Apr} . \\
10 \mathrm{May}\end{array}$ & $\begin{array}{l}27 \text { Feb. } \\
27 \text { Mar. } \\
24 \text { Apr. } \\
22 \text { May }\end{array}$ & $\begin{aligned} 6 & \text { Mar. } \\
3 & \text { Apr. } \\
1 & \text { May } \\
29 & \text { May }\end{aligned}$ & $\begin{array}{l}50 \\
44 \\
34 \\
28\end{array}$ & $\begin{array}{l}0.07 \\
0.06 \\
0.04 \\
0.06\end{array}$ \\
\hline
\end{tabular}

these results after 4,8 and 12 weeks it is clear that differences after 4 weeks were small. Temperatures between $17-25^{\circ} \mathrm{C}$ were better than the ones between $9-$ $17^{\circ} \mathrm{C}$. After 8 and 12 weeks plants of Series 4 were heavier. $17^{\circ} \mathrm{C}$ was the best, $21^{\circ} \mathrm{C}$ the next best temperature for growth.

Comparison of the figures of Series 3 and 4 shows that the effect of light was less pronounced than that of temperature. In the first 4 weeks radiation between 16500 and $29000 \mathrm{~J} / \mathrm{cm}^{2}$ had no effect on growth, but plants grew better at 33000 $\mathrm{J} / \mathrm{cm}^{2}$, especially at the higher temperatures $\left(17-25^{\circ} \mathrm{C}\right)$. The high-energy start resulted in much better growth after 8 and 12 weeks, although the total energy received was nearly the same.

Between the 1972 and 1973 results no weight differences were found after 4 weeks in either experiment, but weights after 8 and 12 weeks were highest in 1972 at $21^{\circ} \mathrm{C}$ and in 1973 at $17^{\circ} \mathrm{C}$. Cuttings from adult plants (Kronenberg, 1971) had an optimum growing temperature of $21^{\circ} \mathrm{C}$, while 4 -month old plants from seeds (2 - 3 months under controlled conditions) grew best at $17^{\circ} \mathrm{C}$. Very young, 2 -month old plants ( 1 month under controlled conditions) grew well at $17-25^{\circ} \mathrm{C}$.

Earlier results (Kronenberg, 1967b) showed that development of the sprouts

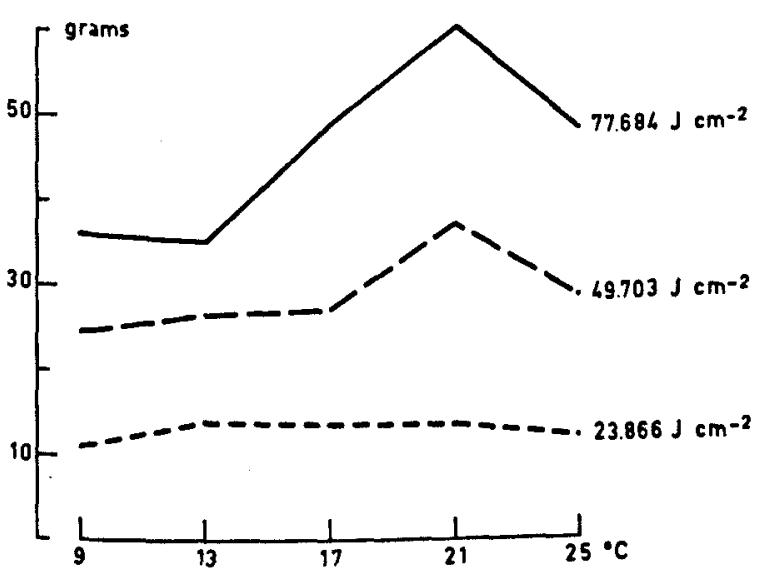

Nerh. J. agric. Sci. 23 (1975)
Fig. 1. Increase of dry weight of young brussels sprout plants from cuttings cv. 'Sanda' after 4, 8 and 12 weeks (1972). 


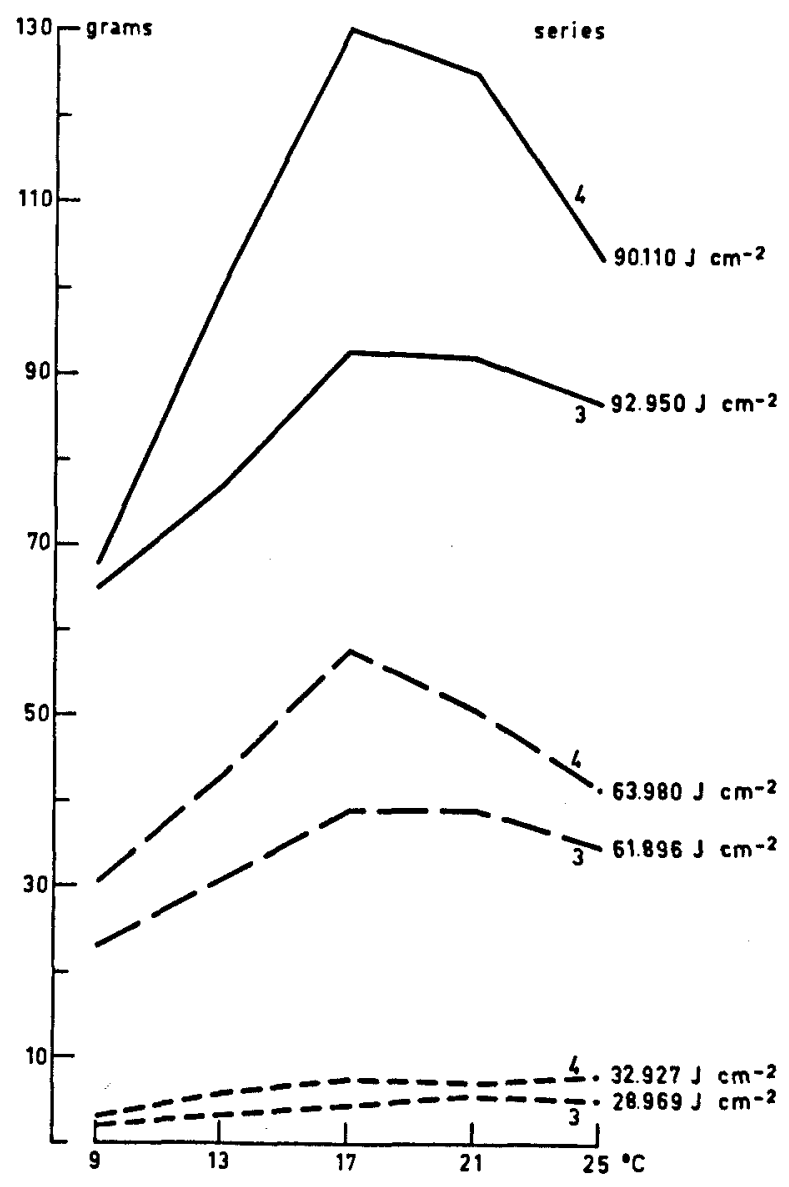

Fig. 2. Increase of dry weight of young brussels sprout plants from seeds cv. 'Thor' in grams after 4, 8 and 12 weeks at various radiation levels (1973).

themselves was better at $12{ }^{\circ} \mathrm{C}$ than at 9 or $15^{\circ} \mathrm{C}$. Flower bud formation required an optimum temperature of $7^{\circ} \mathrm{C}$ (Stokes \& Verkerk, 1950), while higher temperatures were needed for flower stem elongation (Verkerk, 1954) (Fig. 3).

It is clear that the optimum temperatures for growth, flower bud formation and flower bud development are not the same. Similarly optimum temperatures have been found to change with the stage of development in tulip (Hartsema, 1961).

Table 3 gives average temperatures and radiation at De Bilt (Royal Dutch Meteorological Institute) for a comparison between the growth of plants under controlled temperature and plants in the field. Average temperatures at De Bilt are below optimum growing temperatures for the entire year.

Sprout plants grow fastest in July and August; sprout development is best in September and October; flower bud formation starts in November, but flower bud development not before early April of the next year. Radiation intensity between March and September is high enough to permit good plant growth. Plants sown 


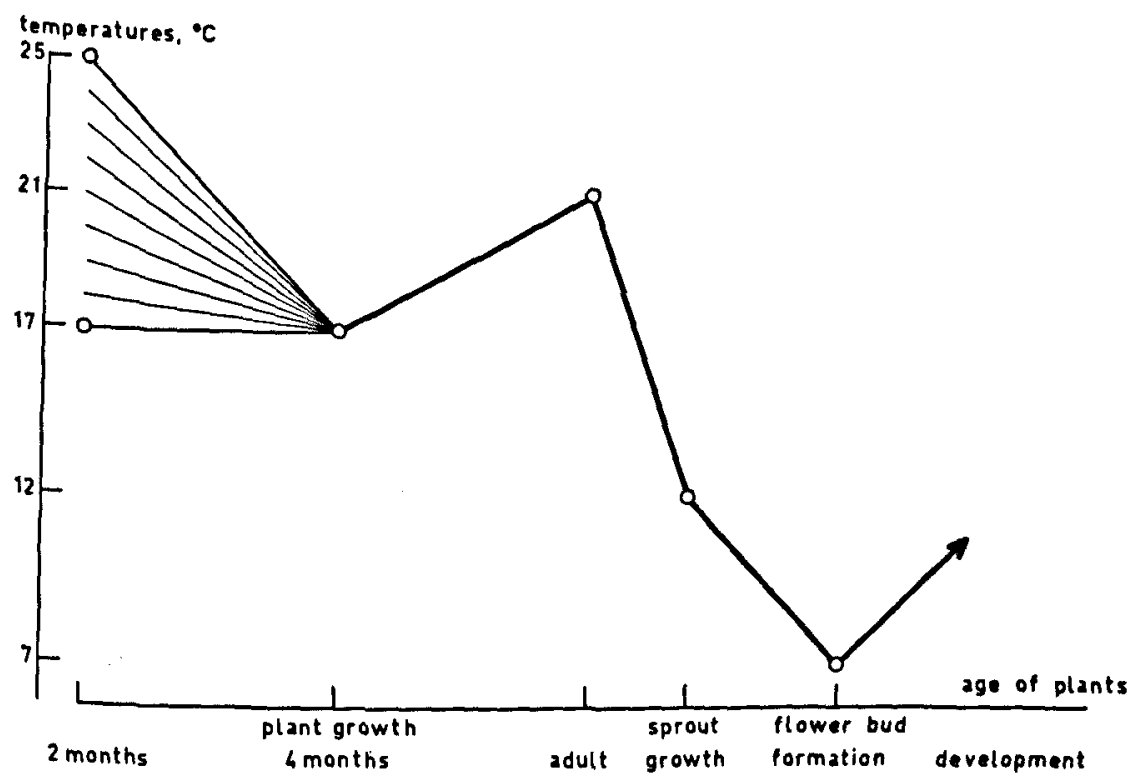

Fig. 3. Optimum temperatures for growth, flower bud formation and development in brussels sprout plants.

in March (which used to be the recommended sowing date) received enough light, but temperatures were too low for optimum growth. Earlier sowing (February under glass) gave slower growth, because radiation was too low. This was clearly demonstrated in Table 2. Plants of Table 2 were grown at $19^{\circ} \mathrm{C}$ in a greenhouse and received $30 \%$ less radiation than in the open.

Table 3. Average temperatures $(1943-1972)$ and average global radiation $(1963-1972)$ at De Bilt (the Netherlands).

\begin{tabular}{llc}
\hline Month & Temperature $\left({ }^{\circ} \mathrm{C}\right)$ & Global radiation $\left(\mathrm{J} / \mathrm{cm}^{2}\right)$ \\
January & 1.7 & 7109 \\
February & 2.0 & 12869 \\
March & 5.0 & 24384 \\
April & 8.5 & 36437 \\
May & 12.4 & 50531 \\
June & 15.5 & 52963 \\
July & 17.0 & 50100 \\
August & 16.8 & 43476 \\
September & 14.3 & 31200 \\
October & 10.0 & 18737 \\
November & 5.9 & 8209 \\
December & 3.0 & 5680 \\
\hline
\end{tabular}


Brussels sprouts could not be grown much earlier in the year without extensive use of heated greenhouses. Even then growing periods would be long.

\section{Acknowledgment}

Many thanks are due to P. A. Sprenkels for the accurate execution of the experiments and to W. J. Kender for correcting the manuscript.

\section{References}

Buishand, Tj., 1973. De teelt van spruitkool. Proefstation voor de groenteteelt in de vollegrond, Alkmaar.

Doorenbos, J., 1964. Het fytotron van het Laboratorium voor Tuinbouwplantenteelt der Landbouwhogeschool. Meded. Dir. Tuinb. 27: 432-437 (English summary).

Hartsema, A. M., 1961. Influences of temperature on flower formation and flowering of bulbous and tuberous plants. Encyl. Pl. Physiol. XVI: 123-167.

Kronenberg, H. G., 1967a. Vegetatieve vermeerdering van spruitkool. Meded. Dir. Tuinb. 30: 314-315 (English summary).

Kronenberg, H. G., 1967b. Probleme bei der einmaligen Rosenkohlernte. SAFA (aug) 18-19.

Kronenberg, H. G., 1971. Adultness in cuttings of Brussels sprout plants. Neth. J. agric. Sci. 19: 37-38.

Stokes, P. \& K. Verkerk, 1950. Flower formation in Brussels sprouts. Meded. LandbHogesch. 50: $141-160$.

Verkerk, K,, 1954. The influence of low temperature on flower initiation and stem elongation in Brussels sprouts. Proc. Kon. Akad. Wet., Serie C, 57: 341-345. 